Cahiers $d u$ MONDE RUSSE

\section{Cahiers du monde russe}

Russie - Empire russe - Union soviétique et États indépendants

$56 / 4 \mid 2015$

Médiateurs d'empire en Asie centrale (1820-1928)

\title{
Valerie Kivelson, Desperate Magic, The Moral Economy of Witchcraft in Seventeenth-Century Russia
}

\section{Kateryna Dysa}

\section{(2) OpenEdition}

1 Journals

\section{Electronic version}

URL: http://journals.openedition.org/monderusse/8234

DOI: $10.4000 /$ monderusse.8234

ISSN: $1777-5388$

\section{Publisher}

Éditions de l'EHESS

\section{Printed version}

Date of publication: 1 October 2015

Number of pages: 802-805

ISBN: 978-2-7132-2507-9

ISSN: $1252-6576$

\section{Electronic reference}

Kateryna Dysa, «Valerie Kivelson, Desperate Magic, The Moral Economy of Witchcraft in Seventeenth-Century Russia », Cahiers du monde russe [Online], 56/4 | 2015, Online since 01 October 2015, Connection on 22 September 2020. URL : http://journals.openedition.org/monderusse/8234 ; DOI : https://doi.org/10.4000/monderusse.8234 


\title{
Valerie Kivelson, Desperate Magic, The Moral Economy of Witchcraft in Seventeenth-Century Russia
}

\author{
Kateryna Dysa
}

\section{REFERENCES}

Valerie KIVELSON, Desperate Magic, The Moral Economy of Witchcraft in

Seventeenth-Century Russia, Ithaca - London : Cornell University Press, 2013, 349 p.

1 Historiography of European witchcraft trials grows larger year after year and already numbers thousands of works. History of Russian witchcraft has also attracted attention of scholars, but the most stimulating and comprehensive studies were written about eighteenth-century Russian witchcraft (works by Aleksandr Lavrov and Elena Smilianskaia). ${ }^{1}$ For some reason, seventeenth-century witch-trials hardly attracted scholars' attention after the early twentieth-century publication of trial materials by N.Ia. Novombergskii ${ }^{2}$. The topic was raised again in the late 1970s by Russel Zguta who presented seventeenth-century Russian witch-trials to the western academic public in several of his articles. ${ }^{3}$ Some aspects of seventeenth-century witchcraft were examined in a comprehensive study of Russian magic by William F. Ryan ${ }^{4}$. Finally, the long-awaited book about the seventeenth-century Russian witch-trials by Valerie Kivelson is available for scholars of witchcraft history.

2 Sources for the research are minutely presented in the second chapter of the book. The author does not state that she managed to collect all the existing materials concerning seventeenth-century Muscovite witchcraft trials, but suggests that her sample (of 227 cases) is quite representative. The majority of the cases Valerie Kivelson uses come from the Military Chancellery (Razriadnyi prikaz), in particular from Prikaznyi stol, as well as a number of cases from Belgorodskii, Vladimirskii, Novgorodskii, and Sevskii stol. She also appeals to previously published witchcraft trial materials (for instance, from 
several publications of the above mentioned N.Ia. Novombergskii), as well as laws and decrees against witchcraft, both published and unpublished.

After the presentation of witchcraft historiography and approaches applicable to the Russian case in the first chapter and specificity of the sources and court procedures in the second, Valerie Kivelson turns her attention to some debatable issues related to Muscovite witch-trials. Quite logically, she starts with the discussion of the distinctive non-diabolical nature of Muscovite magic. Valerie Kivelson calls Russian magic "prosaic" in contrast to Western European, which had a strong demonological stance. Unlike Western European witches who were believed to use dangerous powders and salves made of such ingredients as cat's eyes or bat's wings and whose final aim was to destroy the entire Christian world, Russian witches applied roots and grasses, simple quotidian objects such as salt or kerchiefs in order to achieve their simple ends : to heal or curse, win a court case, find lost belongings, become wealthy, cause impotence or become a successful lover, for example. The demonic almost never entered the stage, because neither theology nor demonology was developed in seventeenth-century Muscovy. That is why it is not surprising that religious and political elites were not interested in investigating diabolical conspiracy: during the interrogation accused witches were never asked about compacts with the Devil, flying or night gatheringthey were not perceived as a threat to the Orthodox people. Even if the accused mentioned "unclean power," the judges were not interested in dwelling on this issue. I would agree with the author that the prosaic nature of Russian magic and almost complete absence of the Devil from the picture make Russian magic different from the Western European case, but I would like to claim that Western European witchcraft cases were also in a way prosaic. As Robin Briggs demonstrated in his Witches and Neighbors, initial accusations of witchcraft were mostly connected with banal quotidian problems, such as illness or death of a family member or cattle, and only in the course of investigation were demonic elements added to the accusation. ${ }^{5}$

In the following two chapters Valerie Kivelson aptly handles another set of problems connected with Russian witchcraft-gender issues. It is a well-established fact that the majority of Russian witches were men. The author counts as much as 74 percent of male witches in her sample. She explains this by specific notion of gender and its implications in Muscovy. For instance, in Russia there was no direct connection between Eve's seduction by the Devil and witchcraft ; sin and magic were not associated exclusively with women. Gendering of witchcraft was not possible in Muscovy, Valerie Kivelson states, because of a rather special gender system and the predomination of a social hierarchy. Women were subordinated to men, but in highly hierarchical society like that of Russia, this subordination was only secondary in comparison to people's subordination to their superiors in status and age. There were more decisive factors than gender regarding the accusation of witchcraft. For example, the most noticeable group of the accused were itinerants and wanderers, followed by people of non-Russian origin, and those who demonstrated disrespect to the existing hierarchy. People who practiced healing composed the most numerous risk group, at 24 percent.

5 Magic specialization is another gender-related matter on which Valerie Kivelson focuses the reader's attention. While in Western European witch-lore evil tongue and ill-temper (qualities associated with witchcraft) were considered exclusively women's vices, in Muscovy women and men alike were guilty of them. On the other hand, magic of the written word (spells written on scraps of paper or "black books") was totally in 
the sphere of males. In the country where the level of rudimentary literacy was extremely low (3-5 percent) and hard to control, the written word was taken as a menace by authorities. Concerning this, I would like to add that this fear of magic of written word makes Russian witchcraft cases differ from other Eastern European cases, such as Ukraine. There are very few references to written spells in Ukrainian witch-trial materials, and magic books were not mentioned at all.

6 Another factor distinguishing the Russian example from other Western and Eastern European witchcraft cases is the unique pattern of counter-accusations formulated by the accused against their social superiors. This aspect is addressed in the sixth chapter, devoted to hierarchical relationships in Muscovite witch-trials-the chapter that has the potential to be the most impressive to the reader. Valerie Kivelson argues that while in most other places kindness and mercy towards the inferiors were virtues like any other, in Muscovy they were necessary expectations from the powerful, as nothing else could soften the cruel existing system of exploitation. It is noteworthy that by "kindness" they referred to the most primitive meaning of the word: the expectation not to kill, not to rape, not to cripple. Remarkably, in cases where this unofficial moral agreement was broken by the superior (be it master or husband), Muscovite authorities were ready to protect even the lesser of the tsar's subjects, even if this person was initially accused of witchcraft. The author provides striking examples of cases in which slaves (mostly women) accused of witchcraft were able to turn the tables on their masters, proving that they exceeded their power by using unspeakable brutality and thus breaching the moral contract. Once again, comparing this to the already mentioned Ukrainian example, nothing even remotely like this could have happened in Ukrainian courts : those socially inferior who were accused of witchcraft by their superiors never managed to escape punishment, but on the other hand, social hierarchy and terms of moral agreement were rather different from Russian ones.

7 In the final two chapters Valerie Kivelson focuses on torture, which connects witchcraft with two other grave offences: heresy and treason. The routine use of torture "without mercy" singles out Russian witchcraft cases from those in many other countries of the so called "periphery" of witchcraft persecution and approximated them to "the cruelest" Western European witch-hunts. The author tries to answer the question of why "prosaic" magic provoked such a harsh response (at least in terms of investigatory procedure) on behalf of authorities, which allowed to put the crime of witches into the same category with that of rebels and heretics (in Muscovy the most severe kinds of torture with application of fire, water and hot pincers were only allowed in the course of investigation of three offences: heresy, treason and witchcraft). Valerie Kivelson believes that this was due to the threat witchcraft represented to society's moral order "at the most intimate and inescapable level."

Desperate Magic is not simply another case study in history of Russian witchcraft trials. Valerie Kivelson addressed a number of problems, essential not only for Russian, but for most of European witchcraft cases-thus tracing similarities and differences between Western European and Russian witchcraft trials. The study is particularly valuable in terms of a methodological and problem-oriented approach that will hopefully stimulate colleagues to think about these problems and share their reflections in further studies. 


\section{NOTES}

1. A.S. Lavrov, Koldovstvo i religiia v Rossii, $1700-1740$ gg. [Witchcraft and religion in Russia, 1700-1740] (M.: Drevlekhranilishche, 2000); E.B. Smilianskaia, Volshebniki, bogokhul'niki, eretiki : Narodnaia religioznost' i “dukhovnye prestupleniia” v Rossii XVIII veke [Wizards, blasphemers, heretics : Popular piety and "spiritual crimes" in eighteenth-century Russia] (M. : Indrik, 2003).

2. N.Ia. Novombergskii, Koldovstvo $\mathrm{v}$ Moskovskoi Rusi XVII veka [Witchcraft in seventeenth-century Muscovite Russia] (SPb. : Tipografiia Al'tshler, 1906).

3. For instance: Russell Zguta. "Witchcraft Trials in Seventeenth-Cetury Russia," American Historical Review 82, 5 (1977) : 1187-1207 ; and "Was There a Witch Craze in Muscotive Russia?," Southern Folklore Quarterly 41 (1977) : 119-128.

4. William F. Ryan, The Bathhouse at Midnight : An Historical Survey of Magic and Divination in Russia (University Park : The Pennsylvania State University Press, 1999).

5. Robin Briggs, Witches and Neighbors : The Social and Cultural Context of European Witchcraft (London : Fontana Press, 1997).

\section{AUTHORS}

\section{KATERYNA DYSA}

Associate Professor of History Department of National University of Kyiv-Mohyla Academy 